\title{
Multi-Criteria Decision-Making Techniques for Improvement Sustainability Engineering Processes
}

\author{
Edmundas Kazimieras Zavadskas ${ }^{1}\left(\mathbb{D}\right.$, Dragan Pamučar ${ }^{2}$, Željko Stević $^{3, * \mathbb{C}}$ and \\ Abbas Mardani 4,5 (D) \\ 1 Department of Construction Management and Real Estate, Laboratory of Operational Research, Research \\ Institute of Sustainable Construction, Vilnius Gediminas Technical University, LT-10223 Vilnius, Lithuania; \\ edmundas.zavadskas@vgtu.lt \\ 2 Department of logistics, Military academy, University of Defence, Belgrade, Pavla Jurišića Šturma 33, \\ 11000 Belgrade, Serbia; dragan.pamucar@va.mod.gov.rs \\ 3 Faculty of Transport and Traffic Engineering, University of East Sarajevo, Vojvode Mišića 52, \\ 74000 Doboj, Republic of Srpska, Bosnia and Herzegovina \\ 4 Informetrics Research Group, Ton Duc Thang University, Ho Chi Minh City 758307, Vietnam \\ 5 Faculty of Business Administration, Ton Duc Thang University, Ho Chi Minh City 758307, Vietnam; \\ abbas.mardani@tdtu.edu.vn \\ * Correspondence: zeljkostevic88@yahoo.com or zeljko.stevic@sf.ues.rs.ba
}

Received: 25 May 2020; Accepted: 25 May 2020; Published: 9 June 2020

\begin{abstract}
The success of any activity and process depends fundamentally on the possibility of balancing (symmetry) needs and their satisfaction. That is, the ability to properly define a set of success indicators. The application of the developed new multi-criteria decision-making (MCDM) methods can be eliminated or decreased by decision-makers' subjectivity, which leads to consistency or symmetry in the weight values of the criteria. In this Special Issue, 40 research papers and one review study co-authored by 137 researchers from 23 different countries explore aspects of multi-criteria modeling and optimization in crisp or uncertain environments. The papers proposing new approaches and elaborate case studies in the following areas of applications: MCDM optimization in sustainable engineering, environmental sustainability in engineering processes, sustainable multi-criteria production and logistics processes planning, integrated approach for modeling processes in engineering, new trends in the multi-criteria evaluation of sustainable processes, multi-criteria decision-making in strategic management based on sustainable criteria.
\end{abstract}

Keywords: multi-criteria decision-making; sustainability; engineering; optimization

\section{Introduction}

Decision making on complex engineering problems including individual process decisions requires an appropriate and reliable decision support system. Fuzzy set theory, rough set theory and neutrosophic set theory which belong to MCDM techniques are very useful for modeling complex engineering problems with imprecise, ambiguous or vague data. Sustainability in engineering is one of the most discussed topics in recent years and represents one of the key factors in engineering sustainable development and optimization. Sustainable multidisciplinary approaches based on MCDM techniques enable easier process technology in the future.

Engineering is the application of scientific and mathematical principles for practical objectives such as the processes, manufacture, design and operation of products, while accounting for constraints invoked by environmental, economic and social factors. There are various factors needing to be considered in order to address engineering sustainability, which is critical for overall the sustainability of human development and activity. In these regards, in recent decades, decision-making theory has 
been a subject of intense research activities due to its wide applications in different areas, such as sustainable engineering and environmental sustainability. The decision-making theory approach has become an important means of providing real-time solutions to uncertainty problems, especially for sustainable engineering and environmental sustainability problems in engineering processes. This Special Issue have stimulated both theoretical and applied research in the related fields of sustainability engineering processes. It is certainly impossible to provide in this short editorial a more comprehensive description for all articles in this Special Issue. However, we can with sure say that effort in compiling these articles have enriched our readers and inspire researchers with regard to the seemingly common, but actually important issue of decision-making and fuzzy decision-making approaches for sustainable engineering processes.

\section{Contributions}

The Special Issue collects 40 original research papers and one review paper written by Guest Editors. The papers contribute to various fields above mentioned. A lot of the research have proposed new methodologies treating uncertainty.

The topics of the Special Issue attracted attention of a wide scientific community: 137 researches from 23 countries contributed to the Issue. Distribution of authors according to countries is shown in Figure 1.

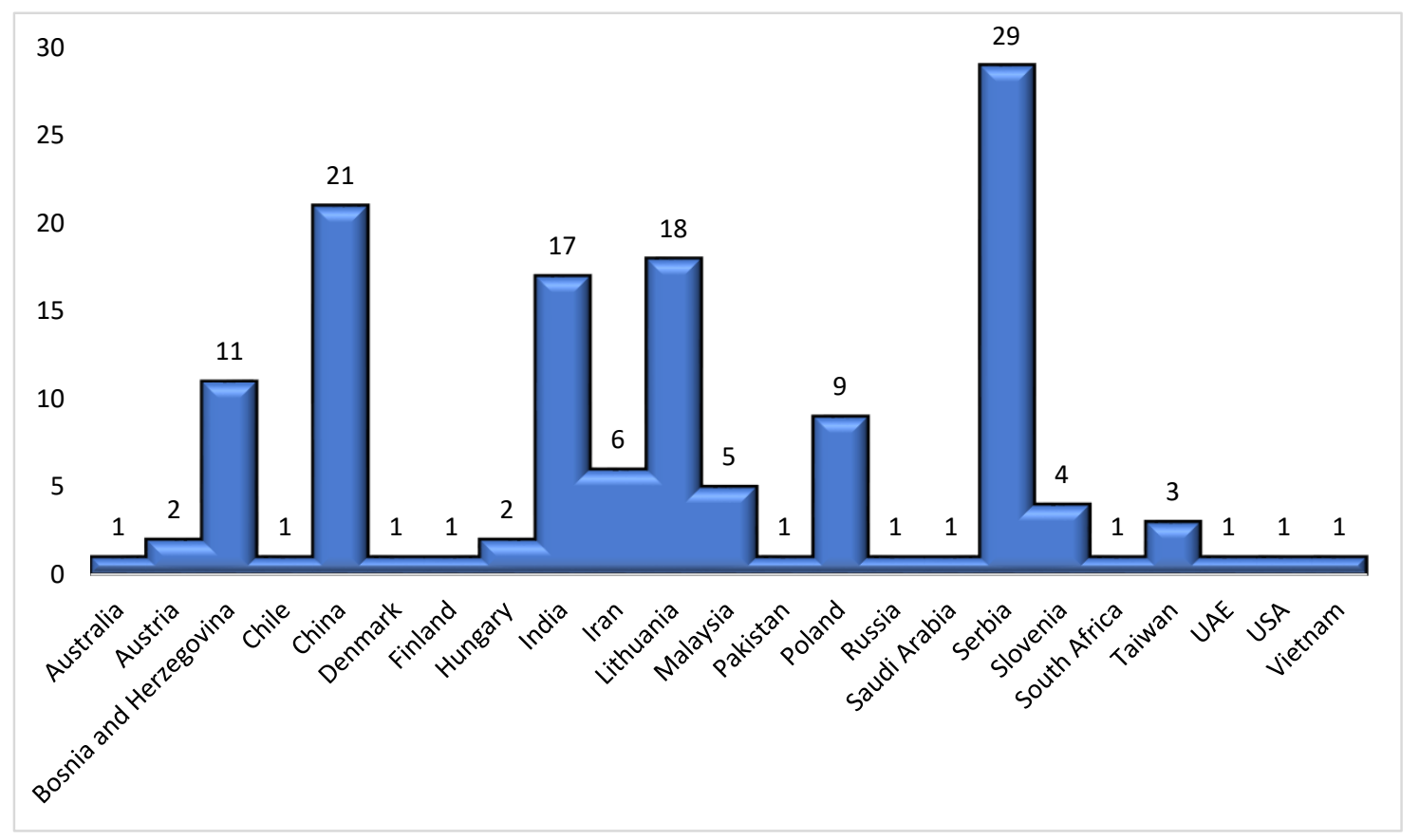

Figure 1. Number of authors from different countries.

The largest number of authors were from Serbia (29 authors). China has 21 authors, while 18 researches come from Lithuania and 17 from India. Bosnia and Herzegovina and Poland contributed almost equally, with 11 and 9 authors, respectively. Next came Iran, with six authors, while five contributors were Malaysia, four from Slovenia and three from Taiwan. Two authors come from Hungary and two from Austria. Authors from the following eleven countries contributed with one paper: Australia, Chile, Denmark, Finland, Pakistan, Russia, Saudi Arabia, South Africa, UAE, USA and Vietnam. It is important note that one researcher contributes with different affiliations from two different countries. He has published three different papers.

Distribution of papers according to authors' affiliations is presented in Table 1. Authors and co-authors from Lithuania contributed 12 papers, five papers without international collaboration [1-5] 
and seven papers with international cooperation: Bosnia and Herzegovina-LithuaniaSerbia-Malaysia [6], Lithuania-Bosnia and Herzegovina-Serbia [7], Iran-Lithuania [8], ChinaLithuania [9], Malaysia-Lithuania [10], Serbia-South Africa-Lithuania-Bosnia and Herzegovina [11] and Chile-Iran-Lithuania-Australia [12]. Authors from China contributed in total eight papers, four without international collaboration [13-16] and four more in international cooperation: [9], China-USA [17], China-Pakistan [18] and Russia-China-Serbia [19]. Authors from Poland contributed four papers, but only to a national cooperation [20-23]. Researchers from Serbia have published 15 papers: three without international cooperation [24-26], four with authors from Bosnia and Herzegovina [27-30], three with authors from India [31-33], mentioned [6,7,11,19], India-Finland-Serbia [34]. Authors from India have published seven papers. Apart from mentioned [31-34] they have cooperated as follow: India-UAE [35], Chile-India [36] and IndiaDenmark-Vietnam-Saudi Arabia [37]. Authors from Slovenia and Taiwan contributed without international cooperation, two papers from Slovenia [38,39] and one from Taiwan [40]. In addition, one study is result of cooperation authors between Hungary and Austria [41]. Two papers come from Malaysia and Chile, while the authors from the following countries contributed per one study in collaboration aforementioned: UAE, Iran, Chile, South Africa, Finland, USA, Pakistan, Australia, Denmark, Vietnam, Saudi Arabia and Russia.

Table 1. Publications by country.

\begin{tabular}{cc}
\hline Countries & Number of Papers \\
\hline Lithuania & 5 \\
China & 4 \\
Poland & 4 \\
Serbia-Bosnia and Herzegovina & 4 \\
Serbia & 3 \\
India-Serbia & 3 \\
Slovenia & 2 \\
Bosnia and Herzegovina-Lithuania-Serbia-Malaysia & 1 \\
Lithuania-Bosnia and Herzegovina-Serbia & 1 \\
India-UAE & 1 \\
Iran-Lithuania & 1 \\
Chile-India & 1 \\
China-Lithuania & 1 \\
Malaysia-Lithuania & 1 \\
Herzegovina & 1 \\
Taiwan & 1 \\
India-Finland-Serbia & 1 \\
China-USA & 1 \\
China-Pakistan & 1 \\
Chile-Iran-Lithuania-Australia & 1 \\
India-Denmark-Vietnam-Saudi Arabia & 1 \\
Russia-China-Serbia & 1 \\
Hungary-Austria & 1 \\
\hline
\end{tabular}

\section{Conclusions}

Guest Editors are very happy that the Special Issue on multi-criteria decision-making techniques for improvement sustainability engineering processes has interested researchers from Europe, Asia and America; papers involving 137 researchers from 23 countries were published.

The Special Issue showed that MCDM techniques are an important tool for solving various problems in the field of sustainability engineering processes. Decision making in real systems requires flexible decisions and respect for the mutual influence between the attributes of the decision. 
Therefore, the authors, have shown the importance of aggregation operators for information fusion in MCDM problems.

Through 40 published papers, the authors have shown the possibilities of applying multicriteria techniques for processing information represented by crisp values, as well as various theories of uncertainty. Uncertainty theories applied in this special edition include traditional fuzzy sets, intuitionistic type-2 fuzzy sets, q-rung orthopair fuzzy sets, q-rung interval-valued orthopair fuzzy sets, rough sets and rough numbers, probabilistic linguistic term sets and neutrosophic sets. The application areas of the proposed MCDM techniques mainly covered production/manufacturing engineering, logistics and transportation and construction engineering and management.

Author Contributions: All authors contributed equally to this work. All authors have read and agreed to the published version of the manuscript.

Conflicts of Interest: The authors declare no conflict of interest.

\section{References}

1. Turskis, Z.; Urbonas, K.; Daniūnas, A. A Hybrid Fuzzy Group Multi-Criteria Assessment of Structural Solutions of the Symmetric Frame Alternatives. Symmetry 2019, 11, 261. [CrossRef]

2. Palevičius, V.; Burinskienè, M.; Antucheviciene, J.; Šaparauskas, J. Comparative Study of Urban Area Growth: Determining the Key Criteria of Inner Urban Development. Symmetry 2019, 11, 406. [CrossRef]

3. Turskis, Z.; Antucheviciene, J.; Keršulienè, V.; Gaidukas, G. Hybrid Group MCDM Model to Select the Most Effective Alternative of the Second Runway of the Airport. Symmetry 2019, 11, 792. [CrossRef]

4. Pavlovskis, M.; Migilinskas, D.; Antucheviciene, J.; Kutut, V. Ranking of Heritage Building Conversion Alternatives by Applying BIM and MCDM: A Case of Sapieha Palace in Vilnius. Symmetry 2019, 11, 973. [CrossRef]

5. Semenas, R.; Baušys, R. Modelling of Autonomous Search and Rescue Missions by Interval-Valued Neutrosophic WASPAS Framework. Symmetry 2020, 12, 162. [CrossRef]

6. Stojčić, M.; Zavadskas, E.K.; Pamučar, D.; Stević, Ž.; Mardani, A. Application of MCDM Methods in Sustainability Engineering: A Literature Review 2008-2018. Symmetry 2019, 11, 350. [CrossRef]

7. Prentkovskis, O.; Erceg, Ž.; Stević, Ž.; Tanackov, I.; Vasiljević, M.; Gavranović, M. A New Methodology for Improving Service Quality Measurement: Delphi-FUCOM-SERVQUAL Model. Symmetry 2018, 10, 757. [CrossRef]

8. Maghsoodi, A.I.; Azizi-Ari, I.; Barzegar-Kasani, Z.; Azad, M.; Zavadskas, E.K.; Antucheviciene, J. Evaluation of the Influencing Factors on Job Satisfaction Based on Combination of PLS-SEM and F-MULTIMOORA Approach. Symmetry 2018, 11, 24. [CrossRef]

9. Zhou, J.; Baležentis, T.; Štreimikienè, D. Normalized Weighted Bonferroni Harmonic Mean-Based Intuitionistic Fuzzy Operators and Their Application to the Sustainable Selection of Search and Rescue Robots. Symmetry 2019, 11, 218. [CrossRef]

10. Bathaei, A.; Mardani, A.; Baležentis, T.; Awang, S.R.; Štreimikienė, D.; Fei, G.C.; Zakuan, N. Application of Fuzzy Analytical Network Process (ANP) and VIKOR for the Assessment of Green Agility Critical Success Factors in Dairy Companies. Symmetry 2019, 11, 250. [CrossRef]

11. Matić, B.; Jovanović, S.; Das, D.; Zavadskas, E.K.; Stević, Ž.; Sremac, S.; Marinković, M. A New Hybrid MCDM Model: Sustainable Supplier Selection in a Construction Company. Symmetry 2019, 11, 353. [CrossRef]

12. Zolfani, S.H.; Dehnavieh, R.; Poursheikhali, A.; Prentkovskis, O. Foresight Based on MADM-Based Scenarios' Approach: A Case about Comprehensive Sustainable Health Financing Models. Symmetry 2019, $12,61$. [CrossRef]

13. Wang, R.; Li, Y.-L. A Novel Approach for Green Supplier Selection under a q-Rung Orthopair Fuzzy Environment. Symmetry 2018, 10, 687. [CrossRef]

14. Wang, J.; Gao, H.; Wei, G.; Wei, Y. Methods for Multiple-Attribute Group Decision Making with q-Rung Interval-Valued Orthopair Fuzzy Information and Their Applications to the Selection of Green Suppliers. Symmetry 2019, 11, 56. [CrossRef]

15. Dai, G.; Yang, C.; Liu, Y.; Jiang, T.; Mgaya, G.B. A Dynamic Multi-Reduction Algorithm for Brain Functional Connection Pathways Analysis. Symmetry 2019, 11, 701. [CrossRef] 
16. Li, X.; Lin, B.; Zhao, Y.-N. Optimizing the Paths of Trains Formed at the Loading Area in a Multi-loop Rail Network. Symmetry 2019, 11, 844. [CrossRef]

17. Quan, H.; Bo, L.S.; Wei, H.; Hu, J. Personalized Product Evaluation Based on GRA-TOPSIS and Kansei Engineering. Symmetry 2019, 11, 867. [CrossRef]

18. Zhou, Y.; Xu, L.; Shaikh, G.M. Evaluating and Prioritizing the Green Supply Chain Management Practices in Pakistan: Based on Delphi and Fuzzy AHP Approach. Symmetry 2019, 11, 1346. [CrossRef]

19. Muravev, D.; Hu, H.; Zhou, H.; Pamučar, D. Location Optimization of CR Express International Logistics Centers. Symmetry 2020, 12, 143. [CrossRef]

20. Śladowski, G.; Szewczyk, B.; Sroka, B.; Radziszewska-Zielina, E. Using Stochastic Decision Networks to Assess Costs and Completion Times of Refurbishment Work in Construction. Symmetry 2019, 11, 398. [CrossRef]

21. Juszczyk, M.; Leśniak, A. Modelling Construction Site Cost Index Based on Neural Network Ensembles. Symmetry 2019, 11, 411. [CrossRef]

22. Sołowczuk, A.; Kacprzak, D. Identification of Determinants of the Speed-Reducing Effect of Pedestrian Refuges in Villages Located on a Chosen Regional Road. Symmetry 2019, 11, 597. [CrossRef]

23. Górecki, J. Simulation-Based Positioning of Circular Economy Manager's Skills in Construction Projects. Symmetry 2019, 12, 50. [CrossRef]

24. Tanackov, I.; Dragić, D.; Sremac, S.; Bogdanović, V.; Matić, B.; Milojevic, M. New Analytic Solutions of Queueing System for Shared-Short Lanes at Unsignalized Intersections. Symmetry 2019, 11, 55. [CrossRef]

25. Zagradjanin, N.; Pamučar, D.; Jovanovic, K. Cloud-Based Multi-Robot Path Planning in Complex and Crowded Environment with Multi-Criteria Decision Making using Full Consistency Method. Symmetry 2019, 11, 1241. [CrossRef]

26. Ranđelović, M.; Nedeljković, S.; Jovanović, M.; Čabarkapa, M.; Stojanović, V.; Aleksić, A.; Ranđelović, D. Use of Determination of the Importance of Criteria in Business-Friendly Certification of Cities as Sustainable Local Economic Development Planning Tool. Symmetry 2020, 12, 425. [CrossRef]

27. Mladenović, S.; Zdravković, S.; Vesković, S.; Janković, S.; Đorđević, Ž.; Đalić, N. Development of a Novel Freight Railcar Load Planning and Monitoring System. Symmetry 2019, 11, 756. [CrossRef]

28. Đorđević, D.; Stojic, G.; Stević, Ž.; Pamučar, D.; Vulevic, A.; Mišić, V. A New Model for Defining the Criteria of Service Quality in Rail Transport: The Full Consistency Method Based on a Rough Power Heronian Aggregator. Symmetry 2019, 11, 992. [CrossRef]

29. Erceg, Ž.; Starčević, V.; Pamučar, D.; Mitrović, G.; Stević, Ž.; Žikić, S. A New Model for Stock Management in Order to Rationalize Costs: ABC-FUCOM-Interval Rough CoCoSo Model. Symmetry 2019, 11, 1527. [CrossRef]

30. Marković, V.; Stajić, L.; Stević, Ž.; Mitrović, G.; Novarlić, B.; Radojičić, Z. A Novel Integrated Subjective-Objective MCDM Model for Alternative Ranking in Order to Achieve Business Excellence and Sustainability. Symmetry 2020, 12, 164. [CrossRef]

31. Kar, M.B.; Roy, B.K.; Kar, S.; Majumder, S.; Pamučar, D. Type-2 Multi-Fuzzy Sets and Their Applications in Decision Making. Symmetry 2019, 11, 170. [CrossRef]

32. Roy, J.; Das, S.; Kar, S.; Pamučar, D. An Extension of the CODAS Approach Using Interval-Valued Intuitionistic Fuzzy Set for Sustainable Material Selection in Construction Projects with Incomplete Weight Information. Symmetry 2019, 11, 393. [CrossRef]

33. Dan, S.; Kar, M.B.; Majumder, S.; Roy, B.; Kar, S.; Pamučar, D. Kar Intuitionistic Type-2 Fuzzy Set and Its Properties. Symmetry 2019, 11, 808. [CrossRef]

34. Sivagami, R.; Ravichandran, K.S.; KrishanKumar, R.; Sangeetha, V.; Kar, S.; Gao, X.-Z.; Pamučar, D. A Scientific Decision Framework for Cloud Vendor Prioritization under Probabilistic Linguistic Term Set Context with Unknown/Partial Weight Information. Symmetry 2019, 11, 682. [CrossRef]

35. KrishanKumar, R.; Ravichandran, K.S.; Ahmed, M.I.; Kar, S.; Tyagi, S. Probabilistic Linguistic Preference Relation-Based Decision Framework for Multi-Attribute Group Decision Making. Symmetry 2018, 11, 2. [CrossRef]

36. Zolfani, S.H.; Chatterjee, P. Comparative Evaluation of Sustainable Design Based on Step-Wise Weight Assessment Ratio Analysis (SWARA) and Best Worst Method (BWM) Methods: A Perspective on Household Furnishing Materials. Symmetry 2019, 11, 74. [CrossRef] 
37. Rani, P.; Govindan, K.; Mishra, A.R.; Mardani, A.; Alrasheedi, M.; Hooda, D.S. Unified Fuzzy Divergence Measures with Multi-Criteria Decision Making Problems for Sustainable Planning of an E-Waste Recycling Job Selection. Symmetry 2020, 12, 90. [CrossRef]

38. Krmac, E.; Djordjević, B. A New DEA Model for Evaluation of Supply Chains: A Case of Selection and Evaluation of Environmental Efficiency of Suppliers. Symmetry 2019, 11, 565. [CrossRef]

39. Robert, O.; Buchmeister, B. The Impact of Manufacturing Flexibility and Multi-Criteria Optimization on the Sustainability of Manufacturing Systems. Symmetry 2020, 12, 157. [CrossRef]

40. Wang, C.-N.; Hsueh, M.-H.; Lin, D.-F. Hydrogen Power Plant Site Selection Under Fuzzy Multicriteria Decision-Making (FMCDM) Environment Conditions. Symmetry 2019, 11, 596. [CrossRef]

41. Moslem, S.; Farooq, D.; Ghorbanzadeh, O.; Blaschke, T. Application of the AHP-BWM Model for Evaluating Driver Behavior Factors Related to Road Safety: A Case Study for Budapest. Symmetry 2020, 12, 243. [CrossRef]

(C) 2020 by the authors. Licensee MDPI, Basel, Switzerland. This article is an open access article distributed under the terms and conditions of the Creative Commons Attribution (CC BY) license (http://creativecommons.org/licenses/by/4.0/). 